\title{
НОРМАТИВНО-ПРАВОВЕ РЕГУЛЮВАННЯ ДІЯЛЬНОСТІ РАД ПРИ ПОПЕЧИТЕЛЯХ НАВЧАЛЬНИХ ОКРУГІВ (1835-1917 РР.)
}

\author{
А. Д. Балацинова
}

Балацинова А. Д. Нормативно-правове регулювання діяльності рад при попечителях навчальних округів (1835-1917 рр.). У статті проаналізовано нормативно-правову базу, що регулювала діяльність рад при попечителях навчальних округів на теренах Російської імперії (1835-1917рp.). Особливу увагу приділено формуванню складу й повноважень попечительських рад Київського, Харківського та Одеського навчальних округів.

Ключові слова: попечительська рада; попечитель; навчальний округ; Міністерство народної освіти; Російська імперія; українські губернії.

Балацинова А. Д. Нормативно-правовое регулирование деятельности советов при попечителях учебных округов (1835-1917 гг.). В статье проанализирована нормативно-правовая база, которая регулировала деятельность советов при попечителях учебных округов на территории Российской империи (1835-1917 гг.). Особое внимание уделено формированию состава и полномочий попечительских советов Киевского, Харьковского и Одесского учебных округов.

Ключевые слова: попечительский совет; попечитель; учебный округ; Министерство народного образования; Российская империя; украинские губернии.

Balatsynova A. D. Legal Framework of the Boards of Trustees of the Educational Districts (18351917). The article analyses legal framework that regulated boards of trustees of the educational districts in the Russian Empire (1835-1917). Particular attention is paid to the composition and powers of the boards of trustees of Kiev, Kharkov and Odessa educational districts.

Keywords: trustee, Board of Trustees; educational district; Ministry of National Education; Russian Empire; Ukrainian governorates.

Початок XIX століття в Російській імперії ознаменувався низкою реформ, зокрема освітньою. Указом імператора Олександра I від 24 січня 1803 року «Про влаштування училищ», що затвердив «Попередні правила народної освіти», в державі запроваджувалася нова освітня система, яка передбачала функціонування чотирьох типів навчальних закладів - парафіяльні, повітові училища, губернські училища або гімназії та університети ${ }^{1}$.

Іншим указом від 24 січня 1803 року «Про заснування навчальних округів, з призначенням для кожного окремих губерній» у межах імперії утворювалося шість навчальних округів за кількістю наявних і тих, що мали відкритися найближчим часом університетів (Московський, Віленський, Дерптський, Харківський, Казанський, Санкт-Петербурзький). Із числа членів Головного правління училищ Міністерства народної освіти призначалися попечителі університетів та їхніх округів².

Згідно з «Попередніми правилами народної освіти» до обов’язків попечителя належало: сприяти поширенню й успіхам народної освіти у ввіреному йому окрузі, подавати на затвердження міністра народної освіти кандидатури професорів університету й директорів гімназій, звітувати про всі поточні справи й витрачені кошти, що виділялися на річне утримання навчальних закладів округу, $\mathrm{i}$, щонайменше, один раз на два роки оглядати їх ${ }^{3}$.

Зауважимо, що як член Головного правління училищ попечитель постійно жив у Санкт-Петербурзі. Функції ж наукових, навчально-методичних та адміністративних центрів навчальних округів виконували університети. Відповідно до університетських статутів 1804 року для керівництва початковими та середніми навчальними закладами округу при радах університетів створювалися спеціальні колегії - училищні комітети 36 ординарних професорів під головуванням ректора, склад яких щорічно переобирався ${ }^{4}$.

Училищний комітет отримував звіти від директорів училищ, зокрема й з господарських питань, надавав їм відповідні дозволи та рекомендації, вносив на розгляд ради університету 
подання на звільнення вчителів і чиновників. Окрім цього члени училищного комітету мали щорічно звітувати перед радою університету про стан навчального процесу, результати іспитів у закладах освіти округу, вносити пропозиції стосовно поширення народної освіти.

Із числа членів училищного комітету та інших професорів університету рада щорічно направляла «візитаторів» (інспекторів) для огляду навчальних закладів округу, про результати яких останні доповідали училищному комітету. Узагальнений звіт заслуховувався на загальних зборах університету й надсилався попечителю навчального округу. Наголосимо, що директори училищ з усіх питань, що стосувалися організації навчального процесу й вирішення фінансово-господарських справ, мали звертатися до училищного комітету. Рішення училищного комітету з навчальних справ вимагали затвердження ради університету, з господарських - його правління 5 .

Утім, після польського повстання 1830-1831 років з метою посилення нагляду за діяльністю навчальних закладів названі функції університетів було передано попечителю. Указом імператора Миколи I від 25 червня 1835 року було затверджено «Положення про навчальні округи Міністерства народної освіти» ${ }^{6}$. Поява цього документа мотивувалася потребою «освободить университеты Наши оть управленія гимназіями и училищами учебных округовъ, столь несовмъстнаго съ умноженіемъ дъятельности высшихъ учебныхъ заведеній, и учредить на сей конецъ новый порядокъ зависимости и отношеній, ближайшій къ существеннымъ пользамъ учебной части въ Имперіи» ${ }^{7}$.

«Положенням про навчальні округи Міністерства народної освіти» уся повнота влади з управління навчальним округом зосереджувалася в руках попечителя. Зокрема, він мав:

- безпосередньо отримувати від керівництва ліцеїв, директорів училищ і гімназій звіти. Зважаючи на суть і важливість справи, приймати рішення самостійно або представляти свої висновки на затвердження міністра народної освіти;

- оглядати особисто або за допомогою свого помічника навчальні заклади округу, залучаючи до цього інспектора казенних училищ, а за необхідності - професора чи ад'юнкта;

- звітувати про результати оглядів навчальних закладів міністру;

- вимагати думку ради університету з усіх навчальних справ, що потребували наукового підходу (удосконалення викладання наук, запровадження додаткових курсів, використання в навчальному процесі книг та інших навчальних посібників тощо), i, якщо вирішення справи належало виключно до компетенції міністра, представляти йому цю думку разом зі своїми висновками;

- самостійно призначати інспекторів гімназій, штатних доглядачів повітових училищ, за поданням директорів - учителів гімназій та повітових училищ;

- подавати на схвалення міністра кандидатури директорів гімназій, почесних наглядачів повітових училищ;

- звільняти за згодою міністра осіб, затверджених ним на посадах, а всіх інших чиновників та вчителів округу - особисто;

- надавати підвідомчим йому навчальним закладам дозволи на одноразові витрати, сума яких не перевищує 1000 рублів асигнаціями;

- затверджувати контракти на підряди й поставки (за штатними та іншими визначеними видатками) на суму до 10000 рублів асигнаціями ${ }^{8}$.

У контексті дослідження наголошуємо, що в Положенні 1835 року вперше знайшли законодавче оформлення правила функціонування рад при попечителях навчальних округів: визначався не тільки склад ради та коло її повноважень, але й регламентувався порядок ухвалення й виконання іiі рішень. Так, раду очолював попечитель навчального округу. У разі його відсутності, хвороби чи зайнятості іншими важливими справами головувати в раді мав його помічник.

Зауважимо, що склад попечительських рад навчальних округів на українських землях, що входили до складу Російської імперії, мав деякі відмінності. Зокрема, у Харківському навчальному окрузі до неї входили: помічник попечителя, ректор університету, інспектор казенних училищ, директор губернської гімназії; у Київському - помічник попечителя, ректор університету, інспектор казенних училищ, директори губернської та інших гімназій; в Одеському - помічник попечителя, директор та інспектор Рішельєвського ліцею, інспектор казенних училищ. 
Попечитель міг запрошувати до ради почесних попечителів і директорів гімназій навчального округу, що перебували в центральному місті округу.

Перелік справ, що обговорювалися під час засідань ради, визначався попечителем. До іiї повноважень належали:

- ініціювання внесення змін до постанов, що стосувалися навчального процесу;

- заснування гімназій та відкриття повітових училищ;

- розгляд річних звітів та результатів огляду навчальних закладів округу;

- заснування та закриття приватних училищ і пансіонів, розгляд піврічних звітів про стан цих закладів;

- розслідування справ про неналежне виконання обов'язків та зловживання училищними чиновниками й учителями;

- розгляд справ про збитки казни та стягнення з приватних осіб, про домагання приватних осіб на казну;

- придбання, побудова, оренда училищних будинків, продаж училищних будівель та іншої власності навчальних закладів;

- надання дозволів на придбання для училищ різних матеріалів та товарів вартістю понад 1000 рублів;

- затвердження контрактів на підряди й поставки на суму понад 10000 рублів.

Показово, що рада ні з ким не мала права вести листування, виконання іiі рішень мало здійснюватися від імені попечителя. На кожному засіданні ради мав вестись окремий протокол, який підписувався головою й усіма присутніми їі членами. У разі, якщо деякі з них були не згодні із загальним рішенням, вони могли додавати до протоколу свою особливу думку. Якщо вирішення справ, що розглядалися на засіданні, було в межах компетенції попечителя, він мав розпорядитися про негайне виконання рішень ради. В іншому разі звернутися до Міністерства народної освіти за їх затвердженням.

Показово, що в разі незгоди більшості членів ради з думкою попечителя, жодна справа не могла бути остаточно вирішена без узгодження з Міністерством. Діловодством ради мала займатися канцелярія попечителя, яка одночасно була й канцелярією ради. На керівника канцелярії покладався обов'язок представлення під час засідань ради необхідних для розгляду того чи іншого питання документів й довідок та ведення протоколів, які він мав скріплювати своїм підписом9

Зауважимо, що загальне положення про округи 1835 року не врахувало деяких місцевих особливостей, зокрема наявності в Київському навчальному окрузі фундушів* і маєтностей, що належали Університету Св. Володимира й училищам цього округу. Miністерству народної освіти довелося пізніше вносити зміни в деякі статті вже підготовленого проекту Статуту Університету Св. Володимира, у порядок управління фундушами й маєтностями цього університету та навчальних закладів Київського навчального округу, що існував до цього часу, а також доповнювати штат управління округом. Міністерською постановою від 20 березня 1836 року було визначено, що управління фундушами й маєтностями надається безпосередньо попечителю Київського навчального округу і його раді, для чого в іiі складі визначається особливий член, а при канцелярії створюється стіл для фундушевих справ, що перебуває у віданні цього особливого члена ${ }^{10}$.

12 вересня 1836 року міністром народної освіти С. С. Уваровим було затверджено «Інструкцію члену ради попечителя Київського навчального округу з управляння фундушами і маєтностями». Згідно $з$ цією інструкцією він був зобов'язаний «заботиться объ учрежденіи наиболъе сообразнаго съ мъстными обстоятельствами управленія имъніями Университета Св. Владиміра и училищъ Округа, объ извлеченіи изъ нихъ сколько возможно большаго дохода, объ охраненіи крестьянъ отъ притъсненій арендаторовъ и другихъ лицъ, о постепенномъ приведеніи имъній въ лучшее положеніе и о своевременномъ и точномъ исполненіи всђхъ распоряженій Правительства, до недвижимыхъ имуществъ Университета и Училищъ Округа относящихся〉 ${ }^{11}$.

На нашу думку, особливої уваги в розвитку досліджуваного феномена заслуговує період 60-70-х pp. XIX століття, коли було прийнято більшу частину нормативно-правових

\footnotetext{
* Фундуш (від поль. fundusz) - рухоме (капітали) та нерухоме майно, яке жертвувалося його власником на користь навчального закладу.
} 
актів, що регулювали діяльність попечительських рад. Так, 20 березня 1860 року указом імператора було затверджено «Положення про ради при попечителях навчальних округів». Поява цього документа була зумовлена необхідністю доповнення III розділу чинного «Положення про навчальні округи Міністерства народної освіти» (1835) у зв'язку з організацією в усіх університетських містах педагогічних курсів для підготовки вчителів i вихователів для середніх навчальних закладів із числа студентів університетів. Згідно 3 «Положенням про педагогічні курси», затвердженим тим же указом, останні були підпорядковані саме радам при попечителях навчальних округів ${ }^{12}$. Однак педагогічні курси при університетах, у тому числі Харківському й Київському Св. Володимира, проіснували лише до 1867 року, коли були ліквідовані у зв'язку із заснуванням у Санкт-Петербурзі Імператорського історико-філологічний інституту як вищого навчального закладу для підготовки вчителів для середніх закладів освіти ${ }^{13}$.

«Положення про ради при попечителях навчальних округів» 1860 року значно розширило їх склад. Так, до попечительських рад навчальних округів українських губерній, крім постійних членів (помічника попечителя, ректора університету, а в Одесі - директора Рішельєвського ліцею, інспектора казенних училищ, директорів гімназій), в університетських містах (Харкові, Києві) для обговорення власне навчальних справ було введено деканів історико-філологічного й фізико-математичного факультетів та шість професорів: російської мови та словесності, стародавніх мов, історії, математики, природничої історії та педагогіки. Професори перших п'яти дисциплін обиралися в члени попечительської ради Радою університету на два роки. Крім того, запрошувалися в попечительську раду вчителі гімназій, коли з їхніх предметів проводилися екзамени для кандидатів-педагогів, керівниками яких вони були призначені на педагогічних курсах, чи коли при обговоренні педагогічних питань рада визнавала необхідною їх присутність як практиків ${ }^{14}$.

Розширювалися повноваження попечительської ради з адміністративних справ. Зокрема, з нею обов'язково погоджувалося придбання для училищ різних матеріалів і товарів, якщо їхня вартість перевищувала 300 рублів сріблом. Також вона затверджувала контракти на підряди й поставки на суму понад 3000 рублів сріблом.

Було розширено й повноваження попечительської ради, що стосувалися власне навчальної частини. Так, до ії обов'язків було віднесено:

- вжиття заходів й обговорення пропозицій щодо поліпшення навчального процесу;

- розгляд і оцінювання навчальних посібників, рекомендація їх для використання в навчальних закладах;

- надання дозволів на прийом кандидатів на педагогічні курси, призначення їм стипендій, розподіл їх по училищах і спостереження за їхніми успіхами;

- проведення іспитів кандидатам, видача їм атестатів на право працювати вчителем чи вихователем;

- збір матеріалів для статистики по округу з навчальних питань.

Крім цього, у штаті управління навчального округу вводилася посада секретаря попечительської ради, визначався час проведення ії̈ засідань і порядок прийняття нею рішень. Зокрема, попечителю як голові ради належало два голоси. У разі незгоди його з думкою більшості, жодна справа не могла бути вирішена остаточно без затвердження міністра народної освіти ${ }^{15}$.

Таким чином, «Положення про ради при попечителях навчальних округів» 1860 року підвищило роль попечительської ради в управлінні навчальними закладами округу. Зазначимо, що згадане положення зберігало свою чинність до 1917 року.

У процесі наукового пошуку встановлено, що в наступні роки склад ради при попечителі навчального округу зазнав деяких змін. Це було зумовлено подальшою розбудовою в Російській імперії системи народної освіти в цілому й системи управління навчальними округами зокрема. Так, імператорським указом від 10 червня 1862 року Рішельєвський ліцей в Одесі перетворювався на Новоросійський університет ${ }^{16}$, що відповідним чином вплинуло на склад попечительської ради Одеського навчального округу.

24 грудня 1863 року імператор Олександр II затвердив думку Державної ради «Про посилення засобів огляду навчальних закладів Міністерства народної освіти і збільшення утримання окружних інспекторів». Згідно з цим документом інспектори казенних училищ перейменовувалися в окружних інспекторів. У штаті управління Київського та Хар- 
ківського навчальних округів передбачалося по 1 окружному інспектору, Одеського - 2 . Окружні інспектори вважалися постійними членами ради при попечителях навчальних округів ${ }^{17}$. У 1866 році до участі у справах попечительських рад було допущено інспекторів прогімназій, які знаходилися в містах перебування попечителів навчальних округів ${ }^{18}$.

Затверджена в 1871 році інструкція інспекторам народних училищ дозволила їм під час перебування в місті, де знаходився попечитель, брати участь 3 правом голосу в усіх засіданнях попечительської ради в справах, що стосувалися початкових народних училищ ${ }^{19}$. Зауважимо, що в 1874 році чинні на той час посади інспекторів народних училищ у губерніях, де було введено земські установи, були перейменовані в директорів народних училищ, які отримали по 2 помічники в званні інспекторів народних училищ ${ }^{20}$.

Згідно 3 § 27 положення «Про учительські інститути», затвердженим 31 травня 1872 року, директори учительських інститутів, що створювалися з метою підготовки учителів для міських училищ, ставали членами попечительської ради навчального округу ${ }^{21}$. Право брати участь у засіданнях попечительської ради місцевого округу з правом голосу отримали того ж року й директори учительських семінарій ${ }^{22}$.

Постійним членом Попечительської ради Київського навчального округу в 1876 році було призначено директора приватного середнього чоловічого закладу - Колегії Павла Галагана, чим його було повністю урівняно в службових правах 3 директорами гімназій відомства Міністерства народної освіти ${ }^{23}$.

Таким чином, у другій половині 70-х років XIX століття майже завершилося формування складу попечительських рад навчальних округів. Останні зміни відбулися на початку XX століття. Постановою Ради міністрів, затвердженою імператором Миколою II 16 листопада 1905 року, попечителям навчальних округів було надано право запрошувати до попечительських рад представників громадських установ - губернських предводителів дворянства, голів губернських управ та міських голів губернських міст ${ }^{24}$. А згідно 3 «Законом про зміну складу попечительських рад» від 28 червня 1914 року до них на правах постійних членів увійшли представник міста, де перебував попечитель навчального округу, а в тих губерніях і областях, у яких було введено «Положення про губернські та повітові земські установи», і представник губернського земства тієї губернії, де перебував попечитель навчального округу. Особи ці обиралися міською думою чи установою, що іiі замінювала, і губернськими земськими зборами відповідно на термін їхніх повноважень, а у тих містах, де не було введено «Міське положення», - на три роки ${ }^{25}$.

У справах, що стосувалися окремих губерній (областей), у попечительських радах засідали на правах членів представник губернського міста відповідної губернії, а в тих губерніях (областях), де було введено «Положення про губернські та повітові земські установи», - і представник губернського земства. Особи ці обиралися відповідними міськими думами й губернськими земськими зборами на термін їхніх повноважень. У тих губерніях (областях), де не було введено «Міське положення», представник губернського міста обирався установою, що замінювала міську думу, на три роки ${ }^{26}$.

Підкреслимо, що, крім складу, зазнали деяких коректив і уточнень повноваження попечительських рад, визначені Положенням 1860 року, що було пов'язано в першу чергу зі зміною обсягу прав і влади попечителів навчальних округів. Так, у 1862 році розпорядженням управителя Міністерства народної освіти попечителю навчального округу було надано право затверджувати розглянутий у попечительській раді розподіл предметів викладання за класами навчальних закладів за умови збереження загального обсягу курсу, визначеного для них ${ }^{27}$.

Цього ж року височайшим повелінням він отримав право дозволяти використання в середніх і нижчих навчальних закладах підручників, схвалених попечительською радою ${ }^{28}$. Проте вже у височайше схвалених «Тимчасових правилах про порядок розгляду, схвалення і введення у вжиток навчальних підручників і посібників для середніх і нижчих навчальних закладів відомства Міністерства народної освіти» від 23 березня 1865 року це право було обмежене. Попечителі могли лише приймати прохання від авторів або видавців про внесення книги чи педагогічної праці до переліку підручників і навчальних посібників та пропонувати їх на розгляд попечительських рад. Висновки останніх передавалися попечителями міністру народної освіти, який і приймав рішення про можливість використання цих книг у навчальних закладах ${ }^{29}$. 
Водночас зауважимо, що 1916 року Рада міністрів за поданням Міністерства народної освіти змінила порядок схвалення навчальних посібників і підручників для навчальних закладів, які видавалися місцевими мовами. Після розгляду таких книг попечительськими радами, попечителі затверджували постанови останніх і лише доводили це рішення до відома Міністерства народної освіти ${ }^{30}$.

24 червня 1863 року імператорським указом було затверджено думку Державної ради, згідно $з$ якою попечителі навчальних округів отримували право після схвалення попечительськими радами видавати дозволи на запровадження в середніх та нижчих навчальних закладах додаткових курсів (відповідно до місцевих потреб), а також на поділ класів на відділення, якщо витрати на це покривалися власними коштами навчального закладу і не перевищували суми, наданої рішенню попечителя ${ }^{31}$.

Правила Головного правління училищ щодо стягнення плати за навчання в середніх і нижчих навчальних закладах, височайше затверджені 2 липня 1863 року, передбачали, зокрема, що подання навчальних закладів стосовно підвищення плати за навчання, а також власні наміри окружного начальства 3 цього питання виконуються не раніше, ніж вони будуть розглянуті в попечительській раді ${ }^{32}$. Така сама норма передбачалася й щодо підвищення плати за вихованців у різних гімназійних пансіонах ${ }^{33}$.

Іменним указом від 19 листопада 1864 року було затверджено «Статут гімназій і прогімназій відомства Міністерства народної освіти», у § 48 якого обов’язок щодо складання інструкції, яка б містила правила випробування учнів під час вступу їх у гімназію і прогімназію, при переведенні з класу в клас і при закінченні ними курсу навчання, покладався на попечительські ради. Ця інструкція мала враховувати думки педагогічних рад усіх гімназій і прогімназій округу й затверджуватися попечителем навчального округу ${ }^{34}$. Проте у новому «Статуті гімназій і прогімназій відомства Міністерства народної освіти», затвердженого іменним указом від 30 липня 1871 року, цю норму було змінено. Тепер єдина для всіх навчальних округів інструкція мала затверджуватися Міністерством народної освіти, що й було зроблено 8 грудня 1872 року ${ }^{35}$. Це стало ще одним свідченням урядового курсу на посилення контролю, централізації й уніфікації у сфері народної освіти за міністерства Д. А. Толстого.

Революційні події 1917 року на теренах Російської імперії призвели до ліквідації навчальних округів, а з ними й посад їхніх попечителів та попечительських рад. Зокрема, законом Центральної Ради від 28 грудня 1917 року навчальні округи на території Української Народної Республіки скасовувалися ${ }^{36}$. Тимчасове завідування справами Київського, Харківського та Одеського навчальних округів, а також проведення їх ліквідації передавалося комісаріатам у складі чотирьох українців і трьох представників національних меншин. Право призначення комісарів надавалося генеральному секретареві народної освіти, який мав узгоджувати кандидатури кандидатів від національних меншин із відповідними секретаріатами. Попечителі та урядовці Київського, Харківського та Одеського навчальних округів звільнялися за штат на загальних засадах. Секретаріату народної освіти доручалося підготувати і внести до Центральної Ради законопроект про передачу справ навчальних округів відповідним секретаріатам, органам місцевого самоврядування тощо.

Зазначимо, що майже одночасно, 21 січня 1918 року, постановою Народного комісаріату освіти на території РРФСР скасовувалися посади попечителів навчальних округів, їхніх помічників, головних і окружних інспекторів, секретарів і помічників секретарів, а також попечительські ради і канцелярії при навчальних округах ${ }^{37}$.

Таким чином, проведений науковий пошук свідчить, що протягом досліджуваного періоду сформувалася доволі струнка нормативно-правова база із законів, іменних указів, постанов, положень, циркулярних розпоряджень, інструкцій тощо, яка регламентувала діяльність колегіальних дорадчих органів при попечителях навчальних округів - попечительських рад. Уперше склад і повноваження попечительських рад навчальних округів на теренах Російської імперії, зокрема Харківського, Київського та Одеського, на законодавчому рівні було відображено у «Положенні про навчальні округи Міністерства народної освіти» 1835 року. Проте більш широка правова основа діяльності досліджуваного феномена склалася із затвердженням у 1860 році «Положення про ради при попечителях навчальних округів», яким розширювалися склад і повноваження цих колегіальних дорадчих органів, що свідчило про спроби уряду демократизувати державну систему управління освітою. 
Саме в цей час більш чітких рис набули: порядок членства в попечительських радах; перелік адміністративних і навчальних справ, що підлягали їх розгляду; процедура прийняття і виконання їхніх рішень; правила ведення діловодства в раді; права й обов'язки попечителя як голови ради, повноваження секретаря тощо. Надалі склад і повноваження попечительських рад зазнавали лише певних коректив у зв'язку з коливаннями урядового курсу, появою нових типів навчальних закладів, розвитком земського самоврядування тощо.

${ }^{1}$ Об устройстве училищ: указ от 24 янв. 1803 г. // Сборник постановлений по Министерству народного просвещения. Т. 1: Царствование императора Александра І. СПб., 1864. Стб. 13-21.

${ }^{2}$ Об учреждении учебных округов: указ от 24 янв. 1803 г. // Сборник постановлений по Министерству народного просвещения. Т. 1: Царствование императора Александра I. СПб., 1864. Стб. 21-22.

${ }^{3}$ Об устройстве училищ. Стб. 16-17.

${ }_{4}^{4}$ Уставы Императорских Московского, Харьковского и Казанского университетов: утвержд. указом от 5 нояб. 1804 г. // Сборник постановлений по Министерству народного просвещения. Т. 1: Царствование императора Александра І. СПб., 1864. Стб. 296-299.

${ }^{5}$ Там само.

${ }^{6}$ Положение об учебных округах Министерства народного просвещения (№ 8262): утвержд. указом от 25 июня 1835 года // Полное собрание законов Российской Империи (далее - ПСЗРИ). Собрание 2-е. Т. Х: 1835. Отд-ние 1: от № 7717-8356. СПб.: Тип. ІІ Отд-ния собств. е. и. в. канцелярии, 1836. C. $756-758$.

${ }^{7}$ Там само. С. 756.

${ }^{8}$ Там само. С. $756-757$.

${ }^{9}$ Там само. С. $757-758$.

${ }^{10}$ Об изменении некоторых статей устава и штата университета Св. Владимира // Сборник постановлений по Министерству народного просвещения. Т. 2: Царствование императора Николая I (1825-1855). Отд-ние 1-е: 1825-1839. СПб.: Тип. Императорской академии наук, 1864. Стб. 850-851.

${ }^{11}$ ЦДІАК України (Центральний державний історичний архів України, м. Київ). Ф. 442. Оп. 68. Спр. 311. Арк. 3-3зв.

${ }^{12}$ Положение о педагогических курсах: утвержд. указом от 20 марта 1860 г. «Об учреждении педагогических курсов и о преобразовании советов при попечителях учебных округов» (№ 35578) // ПСЗРИ. Собрание 2-е. Т. XXXV: 1860. Отд-ние 1-е: от № 35303-36058. СПб.: Тип. II Отд-ния собств. е. и. в. канцелярии, 1862. С. 256-262.

13 Устав Императорского историко-филологического института: утвержд. указом от 27 июня 1967 г. (№ 44767) // ПСЗРИ. Собрание 2-е. Т. XLII: 1867. Отд-ние 1-е: от № 44078-44894. СПб.: Тип. II Отд-ния собств. е. и. в. канцелярии, 1871. С. 1043.

${ }^{14}$ Положение о советах при попечителях учебных округов: утвержд. указом от 20 марта 1860 г. «Об учреждении педагогических курсов и о преобразовании советов при попечителях учебных округов» (№ 35578) // ПСЗРИ. Собрание 2-е. Т. XXXV: 1860. Отд-ние 1-е: от № 35303-36058. СПб.: Тип. ІІ Отд-ния собств. е. и. в. канцелярии, 1862. С. 262.

${ }^{15}$ Там само. С. 263.

${ }^{16}$ О преобразовании Ришельевского лицея в Новороссийский университет в Одессе (№ 38357): указ от 10 июня 1862 г. // ПСЗРИ. Собрание 2-е. Т. XXXVII: 1862. Отд-ние 1-е: от № 37827-38621. СПб.: Тип. ІІ Отд-ния собств. е. и. в. канцелярии, 1865. С. 520.

17 Об усилении средств осмотра учебных заведений Министерства народного просвещения, и увеличении содержания окружных инспекторов (№40426): утвержд. 24 декабря 1863 г. мнение Гос. Совета // ПСЗРИ. Собрание 2-е. Т. XXXVIII: 1863. Отд-ние 2-е: от № 40025-40456. СПб.: Тип. II Отд-ния собств. е. и. в. канцелярии, 1866. С. 321.

${ }_{18} \mathrm{O}$ допущении инспекторов прогимназий, находящихся в местах пребывания попечителей учебных округов, к участию в делах попечительских советов (№ 43123): указ от 18 марта 1866 г. // ПСЗРИ. Собрание 2-е. Т. XLI: 1866. Отд-ние 1-е: от № 42861-43602. СПб.: Тип. II Отд-ния собств. е. и. в. канцелярии, 1868. С. 306.

${ }^{19}$ Инструкция инспекторам народных училищ (№ 50092): утвержд. 29 октября 1871 г. положение Комитета Министров // ПСЗРИ. Собрание 2-е. Т. XLVI: 1871. Отд-ние 2-е: от № 49763-50382 и доп. СПб.: Тип. ІІ Отд-ния собств. е. и. в. канцелярии, 1874. С. 442.

${ }^{20}$ По проекту нового Положения о начальных народных училищах (№ 55574): утвержд. 25 мая 1874 г. мнение Гос. Совета // ПСЗРИ. Собрание 2-е. T. XLIX: 1874. Отд-ние 1-е: от № 52982-53684. СПб.: Тип. ІІ Отд-ния собств. е. и. в. канцелярии, 1876. С. 835.

${ }^{21}$ Положение об учительских институтах (№ 50909): утвержд. 31 мая 1872 г. // ПСЗРИ. Собрание 2-е. T. XLVII: 1872. Отд-ние 1-е: от № 50383-51051. СПб.: Тип. ІІ Отд-ния собств. е. и. в. канцелярии, 1875. C. 734. 
${ }^{22}$ О предоставлении директорам учительских семинарий Министерства народного просвещения права участия, с правом голоса, как в заседаниях попечительских советов местных учебных округов, так и в губернских и уездных училищных советах (№ 51579): утвержд. 27 ноября 1872 г. // ПСЗРИ. Собрание 2-е. Т. XLVII: 1872. Отд-ние 2-е: от № 51052-51723. СПб.: Тип. ІІ Отд-ния собств. е. и. в. канцелярии, 1875. С. 1016.

${ }^{23}$ О назначении директора Коллегии Павла Галагана постоянным членом Попечительского совета Киевского учебного округа (№ 55465): указ от 9 января 1876 г. // ПСЗРИ. Собрание 3-е. Т. Х: 1890. Отд-ние 1-е: от № 6505-7339 и доп. СПб.: Тип. ІІ Отд-ния собств. е. и. в. канцелярии, 1893. С. 119.

${ }^{24}$ О введении в состав советов попечителей учебных округов представителей общественных учреждений // Циркуляр по Харьковскому учебному округу. 1906. № 2. С. 11-12.

25 Закон об изменении состава попечительских советов: 28 июня 1914 г. // Циркуляр по Киевскому учебному округу. 1914. № 8. С. 572.

26 Там само.

$27 \mathrm{O}$ предоставлении окружному начальству разрешать некоторые дела без представления об оных министерству: распоряжение управляющего Министерством народного просвещения // Циркуляр по Харьковскому учебному округу. 1862. № 13. С. 105-106.

${ }_{28} \mathrm{O}$ расширении власти попечителей округов: высочайшее повеление // Циркуляр по Харьковскому учебному округу. 1862. № 19. С. 158.

29 Высочайше одобренные временные правила о порядке рассмотрения, одобрения и введение в употребление учебных руководств и пособий для средних и низших учебных заведений ведомства Министерства народного просвещения // Журнал Министерства народного просвещения. 1865. Ч. CXXVI, отд. I. C. 4-6.

${ }^{30}$ По вопросу об употреблении учебных руководств и пособий на местных языках: положение Совета министров, утвержд. высочайшим повелением от 29 декабря 1906 г. // Циркуляр по Киевскому учебному округу. 1906. № 12. С. 753.

31 О расширении прав и власти президента Академии наук и попечителей учебных округов (№ 39778): утвержд. 24 июня 1863 г. мнение Гос. Совета // ПСЗРИ. Собрание 2-е. Т. XXXVIII: 1863. Отд-ние 1-е: от № 39117-40024. СПб.: Тип. ІІ Отд-ния собств. е. и. в. канцелярии, 1866. С. 672.

32 Относительно взимания платы за учение в средних и низших учебных заведениях: высочайшее повеление от 02 июля 1863 г. // Циркуляр по Харьковскому учебному округу. 1863. № 13, приб. C. 1 .

33 Относительно содержания гимназических пансионов: высочайшее повеление от 01 июля 1863 г. // Циркуляр по Харьковскому учебному округу. 1863. № 13, приб. С. 3.

34 Устав гимназий и прогимназий ведомства Министерства народного просвещения (№ 41472): утвержд. указом от 19 ноября 1864 г. // ПСЗРИ. Собрание 2-е. Т. XXXIX: 1864. Отд-ние 2-е: от № 41319-41641. СПб.: Тип. II Отд-ния собств. е. и. в. канцелярии, 1864. С. 172.

${ }^{35}$ Циркулярное предложение гг. попечителям учебных округов о введении в действие правил об испытаниях учеников гимназий и прогимназий // Журнал Министерства народного просвещения. 1873. Ч. CLXV. C. 32-84.

36 Закон про скасування шкільних округ: закон УНР від 28 грудня 1917 р. // Українська Центральна Рада: документи і матеріали: У 2 т. Т. 2: 10 грудня 1917 р. - 29 квітня 1918 р. / упоряд. В. Ф. Верстюк [та ін.]; ред. В. А. Смолій [та ін.]. К.: Наукова думка, 1997. С. 75.

${ }^{37}$ Об упразднении попечителей учебных округов и их помощников, главных и окружных инспекторов, состоящих при них секретарей и помощников секретарей, а равно попечительских советов и канцелярий при учебных округах: Постановление Народного комиссариата по просвещению РСФСР от 21 января 1918 г. // Собрание узаконений и распоряжений правительства за 1917-1918 гг.: Собрание узаконений и распоряжений рабочего и крестьянского правительства. № 17: 23 января 1918 г. Отд. 1-й / Управление делами Совнаркома СССР. М.: [б. и.], 1942. С. 280. 